\title{
Comparison of antioxidant activities of bovine whey proteins before and after simulated gastrointestinal digestion
}

\author{
Alberto R. Corrochano, ${ }^{1,2}$ Yunus Sariçay, ${ }^{1}$ Elena Arranz, ${ }^{1}$ Phil M. Kelly, ${ }^{1}$ Vitaly Buckin, ${ }^{2}$ and Linda Giblin ${ }^{1 *}$ \\ ${ }^{1}$ Teagasc Food Research Centre, Moorepark, Fermoy, Co Cork, Ireland, P61 C996 \\ ${ }^{2}$ School of Chemistry \& Chemical Biology, University College Dublin, Belfield, Dublin 4, Ireland, D04 V1W8
}

\section{ABSTRACT}

Oxidative stress caused by free radicals has been implicated in several human disorders. Dietary antioxidants can help the body to counteract those reactive species and reduce oxidative stress. Antioxidant activity is one of the multiple health-promoting attributes assigned to bovine whey products. The present study investigated whether this activity was retained during upper gut transit using a static simulated in vitro gastrointestinal digestion (SGID) model. The capacity to scavenge free radicals and reduce ferric ion of whey protein isolate (WPI), individual whey proteins, and hydrolysates pre- and post-SGID were measured and compared using various antioxidant assays. In addition, the free AA released from individual protein fractions in physiological gut conditions were characterized. Our results indicated that the antioxidant activity of WPI after exposure to the harsh conditions of the upper gut significantly increased compared with intact WPI. From an antioxidant bioactivity viewpoint, this exposure negates the need for prior hydrolysis of WPI. The whey protein $\alpha$-lactalbumin showed the highest antioxidant properties post-SGID (oxygen radical absorbance capacity $=1,825.94 \pm 50.21 \mu \mathrm{mol}$ of Trolox equivalents $/ \mathrm{g}$ of powder) of the 4 major whey proteins tested with the release of the highest amount of the antioxidant AA tryptophan, $6.955 \mu \mathrm{mol}$ of tryptophan/g of protein. Therefore, $\alpha$-lactalbumin should be the preferred whey protein in food formulations to boost antioxidant defenses.

Key words: whey protein hydrolysis, antioxidant activity, simulated gastrointestinal digestion, o-lactalbumin

Received February 12, 2018.

Accepted September 11, 2018.

*Corresponding author: linda.giblin@teagasc.ie

\section{INTRODUCTION}

Antioxidants are widely used in the food industry to prevent food oxidation and provide health benefits to the consumer by combating oxidative stress (Capitani et al., 2009). Oxidative stress occurs due to an imbalance between the elimination and production of reactive oxygen, nitrogen, and sulfur species ( $\mathrm{Li}$ et al., 2015). Dietary antioxidants, both soluble and insoluble, can reduce oxidative stress through different pathways, including scavenging free radicals by electron or hydrogen atom transfer (Lü et al., 2010). Antioxidants from plants (polyphenols, carotenoids, and vitamins) are widely accepted as natural antioxidants (Fiedor and Burda, 2014). Once ingested, these bioactive compounds or their metabolites survive gut transit and are transported across the intestinal barrier to reach their target organs (Sarmadi and Ismail, 2010; Quirós-Sauceda et al., 2017). Recently, animal-derived proteins from eggs, meat, and milk have been described as a source of antioxidants (Cloetens et al., 2013; Nimalaratne and Wu, 2015; Liu et al., 2016). In particular, products derived from bovine whey, such as whey protein isolate (WPI) and whey protein concentrate (WPC), have been extensively tested for antioxidant potential in vitro (O'Keeffe and FitzGerald, 2014; Önay-Ucar et al., 2014; Torkova et al., 2016). Indeed, recent human intervention studies with whey product supplementation have reported increased levels of different antioxidant biomarkers in plasma, such as glutathione (de AguilarNascimento et al., 2011; Power-Grant et al., 2016).

Dried whey protein-based ingredients differ primarily in the percentage of protein, fat, and lactose, with WPI containing the highest protein concentration at 90 to $95 \%$. The protein component is considered to harbor the antioxidant activity and is composed of $\beta-\mathrm{LG}$ (50-60\%), $\alpha$-LA (15-25\%), BSA (6\%), lactoferrin (LF; $<3 \%$ ), and immunoglobulins ( $<1 \%$; Madureira et al., 2007). In an effort to increase the antioxidant potency of commercial whey, different processing methods [enzymatic hydrolysis (Zhidong et al., 2013), fractionation (Hernández-Ledesma et al., 2005), thermal treatment 
(Adjonu et al., 2013), pressure treatment (Iskandar et al., 2015), acid treatment (Mohammadian and Madadlou, 2016), and polymerization (Ortega et al., 2015)] have been assessed. It is generally agreed that enzymatic hydrolysis and fractionation increase the antioxidant properties of whey (Power et al., 2013). Hydrolysis with the enzyme alcalase (EC 3.4.21.62) commonly delivers the most potent antioxidant fractions (Lin et al., 2012; Zhang et al., 2013). In addition, whey fractions with a molecular weight below $5 \mathrm{kDa}$ consistently exert better antioxidant properties than higher-molecular weight fractions (de Castro and Sato, 2014; Liu et al., 2014; O'Keeffe and FitzGerald, 2014). Recently, Bamdad et al. (2017) identified 8 peptides present in the most antioxidant fraction of $\beta$-LG hydrolyzed by alcalase.

Once ingested in vivo, whey products are subjected to the chemical (acidic), physical (peristaltic), and enzymatic degradation process of the gastrointestinal tract (Guerra et al., 2012). Given the hydrolytic conditions prevailing in the gastrointestinal tract, it could be argued that enzymatic hydrolysis during whey processing is an unnecessary step to provide the body with antioxidant whey. Indeed, digestion of foods that contain hydrolyzed whey proteins may result in the premature loss of antioxidant activity during gut transit, as hydrolyzed proteins are more easily broken down to individual AA compared with intact protein complexes (Koopman et al., 2009).

Therefore, the objectives of our study were to investigate, under simulated in vitro gastrointestinal digestion (SGID) conditions, whether commercial WPI exposed to the harsh conditions of the upper gut had similar antioxidant activity to WPI hydrolysates prepared with commercial enzymes. We hypothesized that transit of WPI through the upper gut would increase its antioxidant bioactivity to levels comparable to WPI hydrolysate preparations. In addition, individual whey protein fractions (intact and postsimulated upper gut transit) were assayed for antioxidant activity to ascertain the most potent antioxidant product by testing their capacity to counteract free radicals and reduce ferric ion.

\section{MATERIALS AND METHODS}

\section{Materials}

Commercial bovine WPI (Isolac, 91.4\% protein content) was purchased from Carbery Food Ingredients (Ballineen, Co. Cork, Ireland). Individual whey proteins were sourced from food industries as representative of commercial products, except BSA (98\% protein content) which was purchased from Sigma-Aldrich (Dublin, Ireland). The proteins $\beta-\mathrm{LG}$ (92.1\% $\beta$-LG content) and $\alpha$-LA (93\% $\alpha$-LA content) were obtained from Davisco Foods International, Inc. (Le Sueur, MN). The LF (Bioferrin 2000, 95\% LF content) was donated by Glanbia Nutritionals, Inc. (Fitchburg, WI). Bromelain (EC 3.4.22.32) was from Kerry Foods Ingredients (Kilnagleary, Carrigaline, Co. Cork, Ireland), whereas alcalase $2.4 \mathrm{U}$ and neutrase $0.8 \mathrm{~L}$ (EC 3.4.24.28) were from Novozymes (Bagsvaerd, Denmark). Reagents were purchased from Sigma-Aldrich unless stated otherwise.

\section{Enzymatic Hydrolysis of WPI}

Protein powder (WPI 10\%, wt/vol) was hydrated in Milli-Q $\mathrm{H}_{2} \mathrm{O}(300 \mathrm{~mL})$ at $4^{\circ} \mathrm{C}$ stirring overnight. The protein solution was warmed at $50^{\circ} \mathrm{C}$ for $15 \mathrm{~min}$ before starting the hydrolysis. Hydrolysates were produced using the commercial enzymes alcalase (2.4 Anson units/g), bromelain (600 gelatin digestion units/g), or neutrase (0.8 Anson units/g) at an enzyme-to-substrate ratio of $1: 100(\mathrm{~g} / \mathrm{g})$ for $180 \mathrm{~min}$ in a water bath at $50^{\circ} \mathrm{C}$ with continuous stirring. The $\mathrm{pH}$ was maintained constant at 8.0 for alcalase or 7.0 for bromelain and neutrase with $2 M$ solution of $\mathrm{NaOH}$ using a Metrohm 842 Titrando dosing unit (Metrohm Ltd., Herisau, Switzerland). After $180 \mathrm{~min}$, the hydrolysis was stopped by inactivating the enzymes in a water bath at $90^{\circ} \mathrm{C}$ for $10 \mathrm{~min}$. Hydrolysates were freeze-dried and stored at $-80^{\circ} \mathrm{C}$ for further use. Degree of hydrolysis (DH) of these products was determined according to the following equation (Adler-Nissen, 1986):

$$
\% \mathrm{DH}=\frac{\mathrm{B} \cdot \mathrm{N}_{\mathrm{B}}}{\mathrm{M} \cdot \mathrm{h}_{\mathrm{TOT}} \cdot \alpha} \cdot 100,
$$

where $\mathrm{B}(\mathrm{mL})$ is the amount of alkaline solution employed, $\mathrm{N}_{\mathrm{B}}(\mathrm{mol} / \mathrm{L})$ is the molarity of the $\mathrm{NaOH}$ aqueous solution used, $\mathrm{M}(\mathrm{g})$ is the protein mass reacting, $\mathrm{h}_{\text {Tот }}(\mathrm{mEq} / \mathrm{g})$ is the number of total peptides bonds contained in the protein, and $\alpha$ is the dissociation degree of $\alpha$-amino groups that are released during protein hydrolysis. The values $\mathrm{h}_{\text {TOT }}(8.8 \mathrm{mEq} / \mathrm{g})$ and $\alpha$, at $\mathrm{pH} 7$ $(0.441)$ and 8 (0.885), were obtained from Adler-Nissen (1986).

\section{Simulated Gastrointestinal Digestion Static Model}

An in vitro SGID was performed according to an established INFOGEST method (Figure 1; Minekus et al., 2014). Oral phase was not performed, as $1 \mathrm{~g}$ of protein powder was reconstituted in $5 \mathrm{~mL}$ of Milli-Q $\mathrm{H}_{2} \mathrm{O}$. Gastric phase was started by mixing $1 \mathrm{~g}$ of reconstituted protein powder with $2 \mathrm{~mL}$ of simulated gastric 

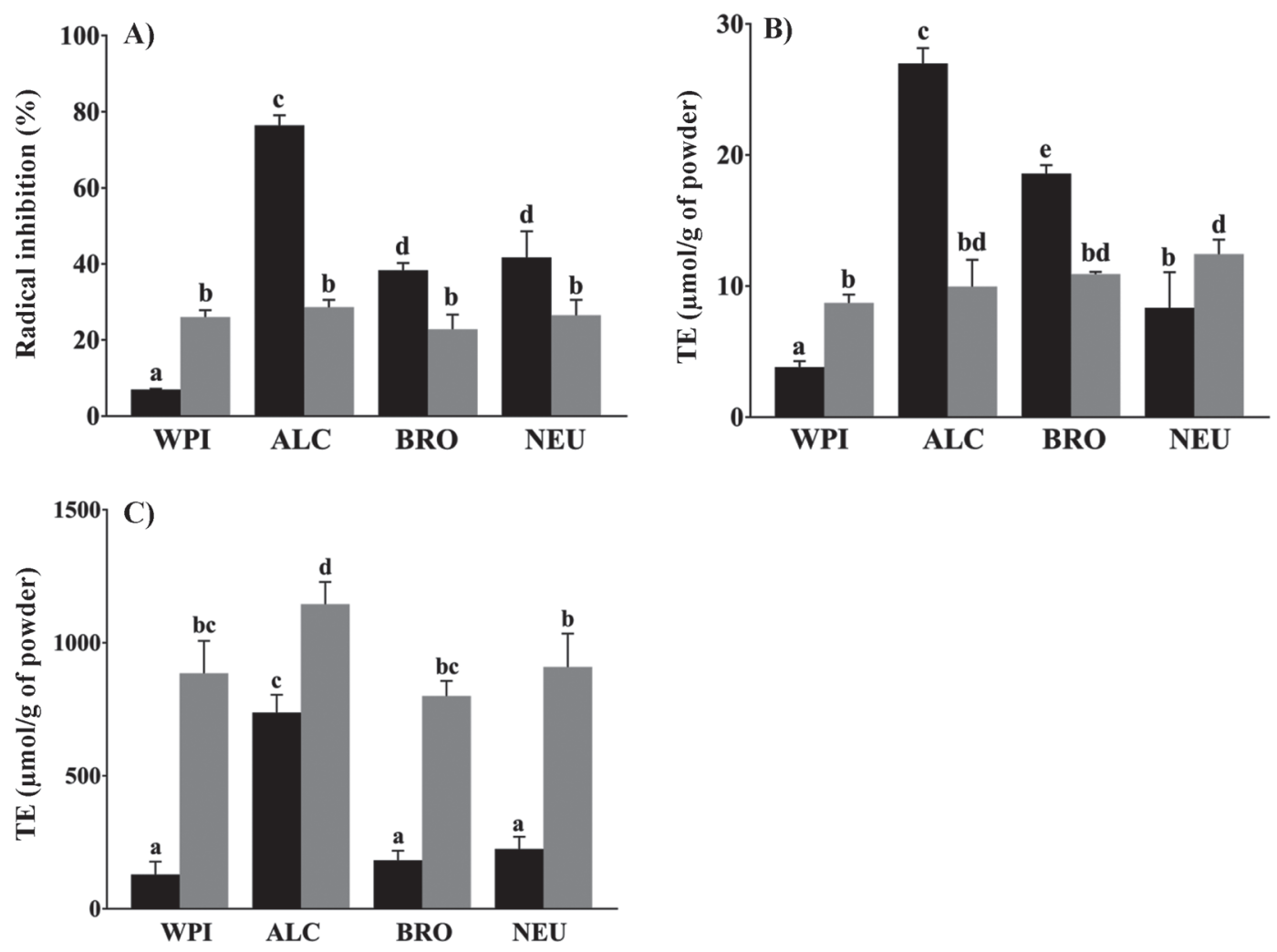

Figure 1. Antioxidant results for nongastrointestinal-digested (black bars) and simulated gastrointestinal-digested (gray bars) whey protein isolate (WPI) and WPI hydrolysates prepared by alcalase (ALC)-, bromelain (BRO)-, or neutrase (NEU)-based hydrolysis. (A) 2,2'-Azinobis(3ethylbenzothiazoline-6-sulfonic acid) (ABTS) values expressed as percent radical inhibition, with samples tested at $15 \mathrm{mg} / \mathrm{mL}$. Results represent the mean of 2 experimental repetitions $\pm \mathrm{SD}(\mathrm{n}=4)$. (B) Ferric-reducing antioxidant power (FRAP) values expressed as micromoles of Trolox equivalents (TE) per gram of powder, samples tested at $15 \mathrm{mg} / \mathrm{mL}$. Results represent the mean of 2 experimental repetitions $\pm \mathrm{SD}(\mathrm{n}=4)$. (C) Oxygen radical absorbance capacity (ORAC) values expressed as micromoles of TE per gram of powder. Results represent the mean of 2 experimental repetitions $\pm \mathrm{SD}(\mathrm{n}=6)$. Samples with different letters $(\mathrm{a}-\mathrm{e})$ are significantly different $(P<0.05)$.

fluid. We then added $2.5 \mathrm{~mL}$ of a fresh stock solution $(8,000 \mathrm{U} / \mathrm{mL})$ of porcine pepsin (EC 3.4.23.1) to reach $2,000 \mathrm{U} / \mathrm{mL}$ activity; $\mathrm{pH}$ was adjusted to 3.0 manually using $\mathrm{HCl}(1 M)$ and volume brought up to $10 \mathrm{~mL}$ with Milli-Q $\mathrm{H}_{2} \mathrm{O}$. The mixture was incubated for $2 \mathrm{~h}$ at $37^{\circ} \mathrm{C}$ with continuous shaking. Pepsin was inactivated by increasing $\mathrm{pH}$ to 6.5 manually using $\mathrm{NaOH}(1 M)$ and by diluting 5 parts of gastric chyme with 4 parts of simulated intestinal fluid. After addition of pancreatin, bile extract, and water, the final ratio of gastric chyme to simulated intestinal fluid was 50:50 ( $\mathrm{vol} / \mathrm{vol}$ ). Pancreatin (EC 232.468.9) and bile extract prepared in simulated intestinal fluid were added to achieve a final concentration of $200 \mathrm{U} / \mathrm{mL}$ and $10 \mathrm{mM}$, respectively. The $\mathrm{pH}$ was adjusted to 7.0, the volume brought up to $20 \mathrm{~mL}$, and the mixture was again incubated for $2 \mathrm{~h}$ at $37^{\circ} \mathrm{C}$ with continuous shaking. After this time, the digestion was stopped by adding the protease inhibitor 4-(2-aminoethyl) benzenesulfonyl fluoride hydrochloride at a final concentration of $1 \mathrm{mM}$. The final sample concentration after SGID was $50 \mathrm{mg}$ of protein powder $/ \mathrm{mL}$. Samples were aliquoted, snap-frozen in liquid nitrogen, and stored at $-80^{\circ} \mathrm{C}$ before analysis. On experimental days, samples were defrosted on ice and diluted, according to the final powder concentration after SGID, to the corresponding assay concentration. The SGID control contained pepsin, pancreatin, and bile salts and it was incubated for the same time as whey test samples. Protease inhibitor was then added and snap frozen.

\section{Determination of the $\mathrm{DH}$}

The extent of hydrolysis was determined using the 2,4,6-trinitrobenzene 1-sulfonic acid (TNBS) method developed by Fernández and Kelly (2016) based on Adler-Nissen (1979). Samples were prepared at $50 \mathrm{mg} /$ $\mathrm{mL}$ and diluted 1:10 in Milli-Q $\mathrm{H}_{2} \mathrm{O}$ prior to assay. Diluted samples $(10 \mu \mathrm{L})$ were mixed with $140 \mu \mathrm{L}$ of SDS (1\%) and $1 \mathrm{~mL}$ of sodium phosphate buffer $(0.2125 \mathrm{M}$, 
$\mathrm{pH}$ 8.2). We then added $1 \mathrm{~mL}$ of $1 \mathrm{mg} / \mathrm{mL}$ TNBS solution to each tube. Tubes were mixed and incubated $1 \mathrm{~h}$ in a covered water bath $\left(50^{\circ} \mathrm{C}\right)$. Reaction was stopped by adding $2 \mathrm{~mL}$ of $\mathrm{HCl}(0.1 \mathrm{M})$. Samples were allowed to cool at room temperature for $30 \mathrm{~min}$ and absorbance was measured at $340 \mathrm{~nm}$ on a Cary 100 Spectrophotometer (Agilent Technologies, Santa Clara, CA). A standard curve using L-leucine was performed to establish the relationship between amino nitrogen content and absorbance. Degree of hydrolysis was determined by comparing the quantity of free amino groups preand postprotein digestion. The following equation was used to calculate the DH of SGID samples:

$$
\% \mathrm{DH}=(\mathrm{AN} 2-\mathrm{AN} 1 / \mathrm{Npb}) \times 100,
$$

where AN1 and AN2 are the amino nitrogen content $(\mathrm{mg} / \mathrm{g}$ of protein) of the protein substrate before and after digestion, respectively, and $\mathrm{Npb}$ is the nitrogen content of the peptide bonds in the protein substrate (mg/g protein). This value is $123.3 \mathrm{mg} / \mathrm{g}$ of protein for whey protein (Adler-Nissen, 1979).

\section{Free AA Determination}

Free AA were determined according to McDermott et al. (2016). Samples after SGID were deproteinized by mixing equal volume of test sample with $24 \%$ (wt/ vol) trichloroacetic acid. The solution was allowed to stand for $10 \mathrm{~min}$ before centrifuging at 14,400 $\times g$ (Microcentaur, MSE, London, UK) for $10 \mathrm{~min}$ at $4^{\circ} \mathrm{C}$. Supernatants were removed and diluted with $0.2 \mathrm{M}$ sodium citrate buffer, $\mathrm{pH}$ 2.2. Samples were then diluted 1 in 2 with the internal standard, norleucine, to give a final concentration of $125 \mathrm{nmol} / \mathrm{mL}$. Amino acids were quantified using a Jeol JLC-500/V amino acid analyzer (Jeol Ltd., Garden City, Herts, UK) fitted with a Jeol $\mathrm{Na}^{+}$high-performance cation exchange column.

\section{Reverse-Phase HPLC and SDS-PAGE}

Hydrolysates, intact whey proteins, the correspondent SGID samples, and the SGID control were analyzed by reverse-phase HPLC in an Agilent 1200 Series with a binary pump and a diode array detector using ChemStation for LC 3D Systems software (Agilent Technologies). Protein and peptide separation was performed at $35^{\circ} \mathrm{C}$ using an Agilent Zorbax StableBond 300SB-C18 column $(4.6 \times 150 \mathrm{~mm}, 5 \mu \mathrm{m})$ with a precolumn security guard (Agilent Technologies). Samples were prepared at a concentration of $0.2 \%$ (wt/vol) in Milli-Q water and $8 \mu \mathrm{L}$ was injected onto the column after filtration through a $0.45-\mu \mathrm{m}$ polyethersulfone syringe filter (Sarstedt AG \& Co., Nümbrecht, Germany).
Mobile phase A was $0.1 \%$ trifluoroacetic acid in Milli$\mathrm{Q}$ water and phase $\mathrm{B}$ was $0.1 \%$ trifluoroacetic acid in HPLC-grade acetonitrile. The flow rate was $0.8 \mathrm{~mL} /$ min and the linear gradient elution was 0 to $10 \mathrm{~min}$ of $5 \% \mathrm{~B} ; 10$ to $20 \mathrm{~min}$ of $10 \% \mathrm{~B} ; 20$ to $22 \mathrm{~min}$ of $15 \%$ B; 22 to $25 \mathrm{~min}$ of $20 \% \mathrm{~B} ; 25$ to $30 \mathrm{~min}$ of $30 \%$ B; 30 to $50 \mathrm{~min}$ of $90 \% \mathrm{~B}$; and 50 to $54 \mathrm{~min}$ of $0 \% \mathrm{~B}$. The absorbance of the eluent was recorded at $214 \mathrm{~nm}$.

We employed SDS-PAGE to analyze protein profile pre- and post-SGID (Laemmli, 1970). Samples were prepared under nonreducing conditions and run on $\mathrm{Nu}-$ PAGE Novex 4-12\% gradient Bis-Tris Mini Gel (Invitrogen, Carlsbad, CA). The Running Buffer MES SDS (Invitrogen) was used with a Xcell SureLock Novex Mini Cell apparatus (Invitrogen). Mark12 Unstained Standard (Invitrogen) was used as the molecular weight standard. Detection of protein bands was performed by gel staining with $0.05 \%$ Coomassie blue solution (Fisher Scientific, Hampton, NH).

\section{Measurement of 2,2'-Azinobis(3- Ethylbenzothiazoline-6-Sulfonic Acid) Radical Scavenging Activity}

The measurement of the 2,2'-azinobis(3-ethylbenzothiazoline-6-sulfonic acid) (ABTS) radical scavenging activity was performed as described by Re et al. (1999) with some modifications. Potassium phosphate monobasic and dibasic were mixed to prepared a potassium phosphate buffer (PB) at $\mathrm{pH}$ 7.0. A $5 \mathrm{~m} M$ potassium persulfate solution was prepared in Milli-Q $\mathrm{H}_{2} \mathrm{O}$. The ABTS diammonium salt radical $(7.3 \mathrm{mM})$ was formed by adding 2 tablets of $10 \mathrm{mg}$ in $5 \mathrm{mM}$ potassium persulfate solution, stirring overnight at $4^{\circ} \mathrm{C}$ in darkness. Absorbance of diluted ABTS solution (1:10 in PB) at $734 \mathrm{~nm}$ was around 0.4. After incubation overnight, the formation of the radical was checked by spectrophotometry (absorbance: 0.8-1.1). The ABTS radical solution was then diluted 1:100 in $10 \mathrm{mM} \mathrm{PB}$ (pH 7.0) and, immediately before use, the absorbance at $734 \mathrm{~nm}$ was checked (0.8-1.1). This solution was kept on ice in the dark to preserve stability. Protein samples were prepared in Milli-Q $\mathrm{H}_{2} \mathrm{O}$ at $15 \mathrm{mg}$ of powder $/ \mathrm{mL}$. The incubation was performed in the spectrophotometer sample holder to ensure dark conditions and eliminate time lost due to sample transfer after the start of the reaction. To perform the assay, $5 \mu \mathrm{L}$ of sample or $\mathrm{PB}$ (control vehicle) was added to a cuvette placed in the spectrophotometer, which contained $1 \mathrm{~mL}$ of ABTS free radical solution. The mixture was homogenized with a pipette and the absorbance was read after 5 min on a Cary 100 Spectrophotometer (Agilent Technologies) at $734 \mathrm{~nm}$. Antioxidant activity was expressed as percent ABTS radical inhibition using the formula 
$\%$ radical inhibition $=\left[\left(\mathrm{Abs}_{734}\right.\right.$ control vehicle

- $\mathrm{Abs}_{734}$ sample) $/ \mathrm{Abs}_{734}$ control vehicle] $\times 100$,

where $\mathrm{Abs}_{734}$ control vehicle is the absorbance measured at $734 \mathrm{~nm}$ of $\mathrm{PB}$ with ABTS radical solution after 5 min of incubation, and $\mathrm{Abs}_{734}$ sample is the absorbance of samples reacting with the radical solution after 5 min. A control for the gastrointestinal fluids, including ions, enzymes, and bile extract, was run and the antioxidant value obtained was subtracted from each SGID sample result.

\section{Ferric-Reducing Antioxidant Power Assay}

Ferric-reducing antioxidant power (FRAP) protocol was performed according to Benzie and Strain (1996) with some modifications to achieve optimum conditions for dairy protein tests. The traditional acetate buffer has a $\mathrm{pH}$ of 3.6, close to the whey acid dissociation constant value (4.6), resulting in protein precipitation. As an alternative, $0.2 \mathrm{M} \mathrm{HCl} / \mathrm{KCl}$ buffer $(\mathrm{pH}=2.2)$ was used. A $10 \mathrm{~m} M$ 2,4,6-tris(2-pyridyl)-s-triazine (TPTZ) solution was prepared in $40 \mathrm{~m} M \mathrm{HCl}$. A $20 \mathrm{~m} M \mathrm{FeCl}_{3}$ solution was prepared using Milli-Q $\mathrm{H}_{2} \mathrm{O}$. All stock solutions were prepared fresh on the experiment day and kept in darkness to avoid photo-oxidation. A working FRAP solution was prepared at low $\mathrm{pH}$ by mixing $0.2 M$ HCl-KCl (pH 2.2) with $10 \mathrm{~m} M$ TPTZ-HCl and $20 \mathrm{mM} \mathrm{FeCl}{ }_{3}$ at a ratio of 10:1:1. This solution was protected from light and heated to $37^{\circ} \mathrm{C}$ for at least 1 $\mathrm{h}$ in a water bath. Test samples were prepared in MilliQ $\mathrm{H}_{2} \mathrm{O}$ at $15 \mathrm{mg}$ of powder $/ \mathrm{mL}$. Trolox (a synthetic analog of vitamin E) was initially dissolved in $200 \mu \mathrm{L}$ of pure methanol. Then, a stock solution was prepared and serial dilutions $(800-25 \mu M)$ in Milli-Q $\mathrm{H}_{2} \mathrm{O}$ were used to generate a standard curve. The reaction was initiated by adding $75 \mu \mathrm{L}$ of sample to $1.425 \mathrm{~mL}$ of FRAP working solution in black microcentrifuge tubes. The mixture was vortexed and allowed to incubate for $1 \mathrm{~h}$ at room temperature in complete darkness. After incubation, tubes were vortexed and the absorbance was read at $593 \mathrm{~nm}$ on a Cary 100 Spectrophotometer (Agilent Technologies). Results were expressed as micromoles of Trolox equivalents (TE) per gram of powder. The antioxidant value for the gastrointestinal fluids was subtracted from SGID sample results.

\section{Oxygen Radical Absorbance Capacity Assay}

The oxygen radical absorbance capacity (ORAC) assay protocol was adapted from Zulueta et al. (2009). A potassium $\mathrm{PB}$ at $75 \mathrm{~m} M, \mathrm{pH} 7.2$, was prepared.
Digested assays were run using $0.05 \mathrm{mg} / \mathrm{mL}$ of test samples and then expressed per gram of powder. Intact assays were run using $0.1 \mathrm{mg} / \mathrm{mL}$ of test samples and expressed as above. Samples, standards, or vehicle control $(\mathrm{PB} ; 20 \mu \mathrm{L})$ were pipetted into a black 96-well microtiter plate followed by $120 \mu \mathrm{L}$ of $0.117 \mu \mathrm{M}$ fluorescein solution, freshly prepared in $\mathrm{PB}$. The plate was incubated at $37^{\circ} \mathrm{C}$ for $15 \mathrm{~min}$. During this period, a $40 \mathrm{~m} M$ 2,2'-azobis(2-methylpropionamidine) dihydrochloride (APPH) radical solution was prepared in preheated $\mathrm{PB}$ and kept at $37^{\circ} \mathrm{C}$. After incubation, 60 $\mu \mathrm{L}$ of APPH solution were added to each well. The fluorescence was immediately read at 90-s intervals for $2 \mathrm{~h}$ in a Synergy HT BioTek micro plate reader (Winooski, VT). A standard curve was performed with Trolox at 5 different concentrations ranging from 80 to $5 \mu M$ prepared in $75 \mathrm{mM}$ PB. Trolox was initially dissolved in $200 \mu \mathrm{L}$ of methanol, as described previously. Fluorescence data were normalized and area under the curve was calculated. The antioxidant reaction was considered to be finished if the final fluorescence was less than $5 \%$ of the initial value. Antioxidant activity was expressed as micromoles of TE per gram of powder. The antioxidant value for the gastrointestinal fluids was subtracted from SGID sample results.

\section{Statistical Analysis}

Results were compared using one-way ANOVA followed by Bonferroni's multiple comparison post-hoc test using PASW Statistics 18 software; a $P$-value less than 0.05 was considered to indicate a statistically significant difference. Results were expressed as mean \pm standard deviation. Each experiment was repeated at least in duplicate and on different days.

\section{RESULTS}

\section{In Vitro Antioxidant Activity of WPI}

The antioxidant activity of intact WPI and WPI hydrolysates prepared by 3 individual commercial enzymes (bromelain, neutrase, and alcalase) is detailed in Figure 1. Bromelain, a cysteine protease obtained from pineapple (Abadía-García et al., 2016), was selected because it exposes the reactive thiol group of cysteine residues so that they are available to reduce oxidative agents such as peroxyl radicals. Neutrase is a bacterial metalloprotease, commonly used to improve food protein functionality with an affinity for the AA leucine and phenylalanine (Xu et al., 2014). Alcalase is a nonspecific endopeptidase purified from Bacillus licheniformis. Not surprisingly, commercial enzyme hydrolysates 
showed significantly higher ABTS and FRAP values than intact WPI $(P<0.05)$. In particular, alcalase hydrolysis of WPI resulted in $76.41 \pm 2.67 \%$ ABTS radical inhibition, $26.96 \pm 1.18 \mu \mathrm{mol}$ of $\mathrm{TE} / \mathrm{g}$ of powder by FRAP, and $737.36 \pm 67.24 \mu \mathrm{mol}$ of TE/g of powder by ORAC assay compared with intact WPI $(6.98 \pm 0.18 \%$ ABTS radical inhibition, $3.81 \pm 0.46 \mu \mathrm{mol}$ of $\mathrm{TE} / \mathrm{g}$ of powder by FRAP, and $128.74 \pm 48.36 \mu \mathrm{mol}$ of $\mathrm{TE} / \mathrm{g}$ of powder by ORAC; Figure 1A, B and C). Bromelain and neutrase hydrolysis of WPI resulted in significantly higher antioxidant activity than intact WPI by FRAP and ABTS $(P<0.05)$, but we observed no difference in TE as determined by ORAC (Figure 1A, B and C).

The standardized INFOGEST static in vitro digestion model was employed to ascertain if simulated upper gut transit altered the antioxidant bioactivity of these WPI samples (Figure 1). In all 3 assays, the antioxidant activity of WPI was significantly increased post-SGID $(P<0.05)$. Remarkably, when subjected to the hydrolytic conditions of the gastrointestinal tract, whey hydrolysates produced by alcalase exhibited significantly lower FRAP and ABTS inhibition than the alcalase-hydrolyzed sample without gastric digestion (Figure 1A and B). However, ORAC activity was increased by SGID of the WPI hydrolysate prepared by alcalase $(1,144.73 \pm 83.86 \mu \mathrm{mol}$ of $\mathrm{TE} / \mathrm{g}$ of powder $)$. Reduction in antioxidant activity by FRAP and ABTS inhibition, but not by ORAC, was also observed with the bromelain-hydrolyzed WPI (Figure 1A, B, and C). The WPI hydrolyzed by neutrase and subjected to SGID exhibited significantly $(P<0.05)$ lower antioxidant activity by ABTS inhibition but significantly higher antioxidant activity by ORAC and FRAP (Figure 1A, $\mathrm{B}$, and $\mathrm{C}$ ). Interestingly, subjecting commercial WPI to hydrolysis by either bromelain or neutrase before SGID did not enhance its antioxidant activity, 799.93 \pm 56.68 and $908.65 \pm 126.11 \mu \mathrm{mol}$ of $\mathrm{TE} / \mathrm{g}$ of powder, respectively, compared with WPI post-SGID (885.18 $\pm 121.91 \mu \mathrm{mol}$ of $\mathrm{TE} / \mathrm{g}$ of powder) as determined by ORAC. Only alcalase hydrolysis contributed to higher ORAC value post-SGID compared with the results obtained for WPI post-SGID. Hydrolysates generated by alcalase or bromelain had similar FRAP capabilities to WPI post-SGID (Figure 1B). Only neutrase hydrolysis of WPI post-SGID was significantly better at reducing ferric ions than WPI post-SGID. In the case of ABTS inhibition, commercial enzyme hydrolysis of WPI was not significantly different post-SGID compared with WPI post-SGID (Figure 1A). Antioxidant activity measured after SGID of WPI was significantly higher when measured by ORAC compared with the hydrolysates prepared with the commercial enzymes bromelain or neutrase (Figure 1C). The FRAP capability of WPI post-SGID was similar to alcalase- and bromelain-hy- drolyzed WPI (Figure 1B). The WPI post-SGID inhibited less ABTS $(26.02 \pm 1.84 \%)$ than alcalase $(76.41 \pm$ $2.67 \%)$, bromelain $(38.33 \pm 1.91 \%)$, or neutrase $(41.69$ $\pm 6.89 \%$ ) hydrolyzed WPI (Figure 1A).

\section{DH of WPI}

To compare the extent of hydrolysis, DH values were obtained for whey samples. The WPI post-SGID had a DH of $49.96 \%$, with alcalase hydrolysis of WPI yielding $13.60 \%$ followed by neutrase, $5.28 \%$, and bromelain, $4.31 \%$. However, the comparative kinetics have not been investigated here. Degradation of WPI after hydrolysis with commercial enzymes and after SGID was also evaluated by HPLC (Figure 2). The profile of intact WPI revealed clear peaks correspondent to the caseinomacropeptide, BSA, $\alpha-\mathrm{LA}$, and $\beta-\mathrm{LG}$ (retention times of 31-42 $\mathrm{min}$ ). The use of alcalase, bromelain, and neutrase showed distinct WPI peptide peaks explained by the diverse enzyme specificity. Fractions at lower retention times contained hydrophilic peptides with higher polarity, whereas hydrophobic peptides with less polarity were eluted at higher retention times. Alcalase hydrolysis resulted in a large number of peaks, primarily at 24 to $33 \mathrm{~min}$. However, bromelain hydrolysates, with the lowest $\mathrm{DH}$, had the least number of peptide peaks (18-19 and 29-31 min). The major peptides obtained after neutrase hydrolysis appeared at the highest retention time (24-39 min), which could explain its poor solubility in water. The chromatograms of each hydrolysate showed further degradation of whey peptides after being exposed to gut conditions. After this breakdown, hydrolysates presented similar HPLC profiles to the chromatogram obtained for WPI after SGID. The HPLC profiles of SGID samples revealed several peaks that corresponded to the hydrolytic activity of pancreatin. The HPLC profile of SGID control did not indicate significant autocatalysis.

\section{In Vitro Antioxidant Activity of Individual Whey Proteins}

To identify which whey protein fraction contributed to greater antioxidant activity, individual whey proteins $\beta-\mathrm{LG}, \alpha-\mathrm{LA}, \mathrm{BSA}$, and LF were assessed for their antioxidant activity before and after SGID (Figure 3). Intact $\alpha$-LA $(20.97 \pm 1.44 \%)$ and LF $(18.06 \pm 0.44 \%)$ were the most effective at inhibiting the radical cation ABTS compared with the other intact proteins $(P>$ $0.05)$. These samples also exerted the most potent ferric to ferrous ion reduction, tested by FRAP assay (intact $\alpha$-LA $=8.19 \pm 1.19 \mu \mathrm{mol}$ of $\mathrm{TE} / \mathrm{g}$ of powder; intact $\mathrm{LF}=7.85 \pm 0.84 \mu \mathrm{mol}$ of $\mathrm{TE} / \mathrm{g}$ of powder). All intact proteins showed peroxyl radical inhibition with values 
ranging from $117.65 \pm 37.23 \mu \mathrm{mol}$ of $\mathrm{TE} / \mathrm{g}$ of powder for $\mathrm{LF}$ and $365.14 \pm 46.07 \mu \mathrm{mol}$ of $\mathrm{TE} / \mathrm{g}$ of powder for $\alpha$-LA. Antioxidant activity of all proteins appeared significantly enhanced after $240 \mathrm{~min}$ of exposure to the $\mathrm{pH}$ and enzymes of the stomach and duodenum. Of note was $\alpha$-LA post-SGID, which exhibited the highest antioxidant activity by all 3 methods (37.29 $\pm 0.73 \%$ ABTS inhibition; FRAP $=15.56 \pm 1.21 \mu \mathrm{mol}$ of $\mathrm{TE} / \mathrm{g}$ of powder; $\mathrm{ORAC}=1,825.94 \pm 50.21 \mu \mathrm{mol}$ of $\mathrm{TE} / \mathrm{g}$ of powder).

\section{DH of Individual Whey Proteins by Simulated Upper Gut Transit}

The DH of whey protein samples was determined after SGID by the TNBS method. Values ranged from
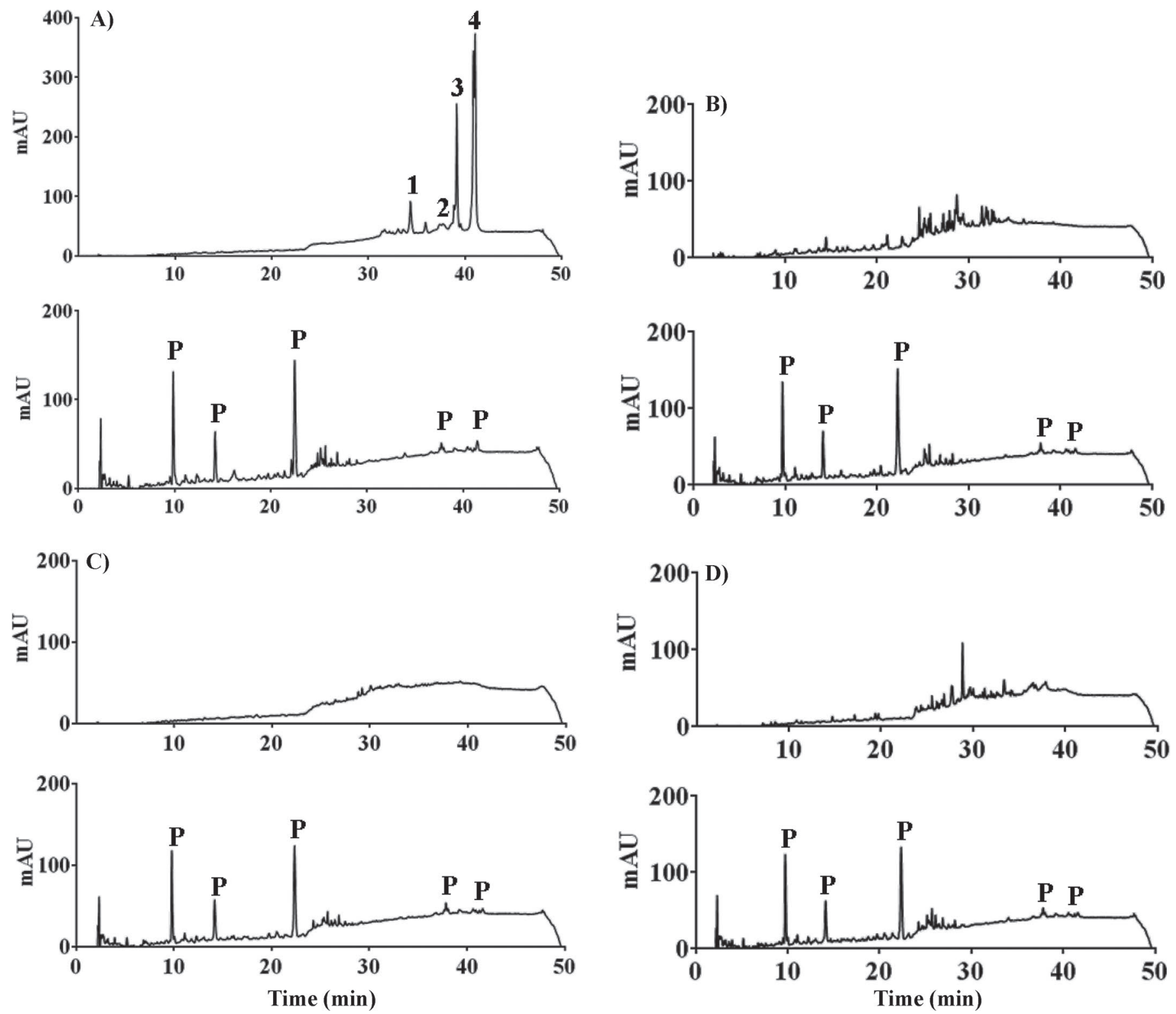

Figure 2. Reverse-phase HPLC profiles at $214 \mathrm{~nm}$ for whey protein isolate (WPI) and whey protein hydrolysates. Samples were prepared at $2 \mathrm{mg} / \mathrm{mL}$ and eluted in $0.1 \%$ trifluoroacetic acid. (A) Intact WPI and the graph below it simulated gastrointestinal-digested (SGID) WPI, where individual peaks correspond to (1) caseinomacropeptide, (2) BSA, (3) $\alpha$-LA, and (4) $\beta$-LG; (B) WPI hydrolyzed with alcalase for 180 min at $50^{\circ} \mathrm{C}, \mathrm{pH} 8.0$, with an enzyme-to-substrate ratio of 1:100 and associated SGID sample; (C) WPI hydrolyzed with bromelain for 180 min at $50^{\circ} \mathrm{C}, \mathrm{pH} 7.0$, with an enzyme-to-substrate ratio of 1:100 and associated SGID sample; and (D) WPI hydrolyzed with neutrase for 180 min at $50^{\circ} \mathrm{C}, \mathrm{pH} 7.0$, with an enzyme-to-substrate ratio of 1:100 and associated SGID sample. Pancreatin peaks from SGID process are indicated by P. The HPLC profiles of SGID control without WPI were also performed. AU = arbitrary units. 

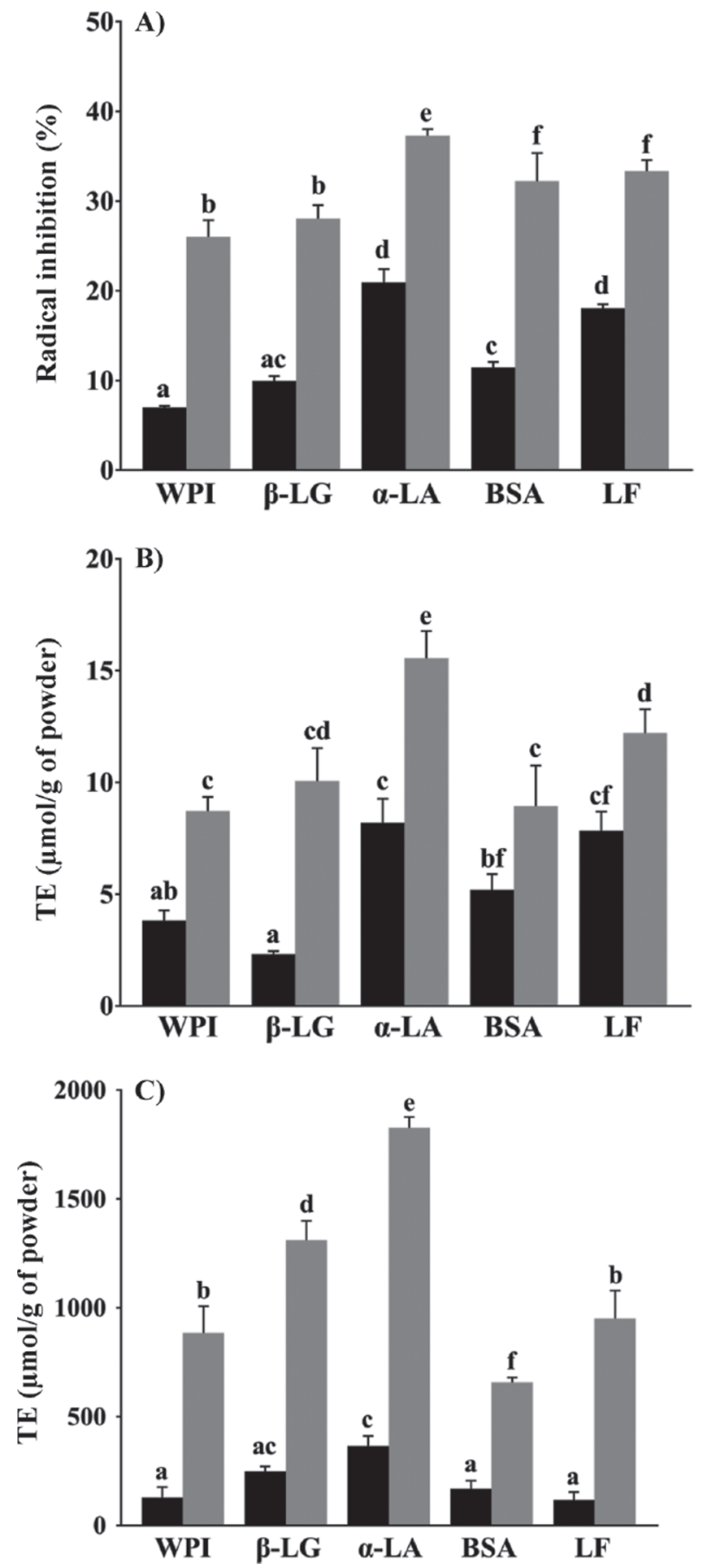

Figure 3. Antioxidant results for intact (black bars) and simulated gastrointestinal-digested (gray bars) proteins. (A) 2,2'-Azinobis(3ethylbenzothiazoline-6-sulfonic acid) (ABTS) values are expressed as percent ABTS radical inhibition, samples tested at $15 \mathrm{mg} / \mathrm{mL}$. Results represent the mean of 2 experimental repetitions $\pm \mathrm{SD}(\mathrm{n}=4)$. (B) Ferric-reducing antioxidant power (FRAP) values are expressed as micromoles of Trolox equivalents (TE) per gram of powder, samples tested at $15 \mathrm{mg} / \mathrm{mL}$. Results represent the mean of 2 experimental repetitions $\pm \mathrm{SD}(\mathrm{n}=4)$. (C) Oxygen radical absorbance capacity (ORAC) values are expressed as micromoles of TE per gram of powder. Results represent the mean of 2 experimental repetitions \pm SD $(\mathrm{n}=6) . \mathrm{WPI}=$ whey protein isolate; $\mathrm{LF}=$ lactoferrin. Samples with different letters $(\mathrm{a}-\mathrm{f})$ are significantly different $(P<0.05)$.
Table 1. Degree of hydrolysis (DH, \%) of whey protein isolate (WPI) and individual whey protein fractions following simulated gastrointestinal digestion (SGID)

\begin{tabular}{ll}
\hline Sample $^{1}$ & DH $(\%)$ \\
\hline SGID WPI & $49.96 \pm 1.95^{\mathrm{a}}$ \\
SGID $\beta$-LG & $64.78 \pm 4.66^{\mathrm{ab}}$ \\
SGID $\alpha$-LA & $57.59 \pm 1.06^{\mathrm{ab}}$ \\
SGID BSA & $65.10 \pm 4.61^{\mathrm{b}}$ \\
SGID LF & $62.62 \pm 0.91^{\mathrm{ab}}$ \\
\hline
\end{tabular}

${ }^{\mathrm{a}, \mathrm{b}}$ Samples with different letters are significantly different $(P<0.05)$.

${ }^{1}$ Samples tested at $5 \mathrm{mg} / \mathrm{mL}, \mathrm{LF}=$ lactoferrin.

$49.96 \pm 1.95 \%$ for WPI to $65.10 \pm 4.61 \%$ for BSA (Table 1). The chromatograms of the intact whey proteins (Figure 4$)$ showed distinct peaks $(\beta-\mathrm{LG}=40-42$ $\min , \alpha-\mathrm{LA}=38.5-40 \mathrm{~min}, \mathrm{BSA}=37.5-39.5 \mathrm{~min}, \mathrm{LF}=$ 33 and 38.5-39.5 min), indicating a high level of native conformation. After SGID, these peaks disappeared, which indicated native protein degradation. The loss of each intact whey protein after the harsh conditions of the stomach and duodenum was supported by SDSPAGE (Figure 5).

\section{Free AA Content in Gastrointestinal-Digested Whey Proteins}

To determine if the high antioxidant activity of $\alpha-\mathrm{LA}$ could be explained by the free AA released after SGID, AA analysis was performed on WPI and individual whey protein fractions post-SGID (Table 2). The highest concentration of free AA $(50.426 \mu \mathrm{mol}$ of $\mathrm{AA} / \mathrm{g}$ of powder) was released from $\alpha$-LA. Leucine was the predominant AA in SGID of WPI, $\beta$-LG, BSA, and LF $(6.208-8.154 \mu \mathrm{mol} / \mathrm{g}$ of powder). Lysine was the most abundant $(8.154 \mu \mathrm{mol} / \mathrm{g}$ of powder $) \mathrm{AA}$ found in $\alpha-\mathrm{LA}$ post-SGID. Interestingly, proline was not detected in any of the samples, which can be explained by the lack of specificity of the human gastrointestinal enzymes for this AA. Known antioxidant AA, such as tryptophan, phenylalanine, tyrosine, cysteine, and histidine (Hernández-Ledesma et al., 2005; Power-Grant et al., 2016), were present at relatively high concentrations in all SGID samples compared with other AA. Interestingly, $\alpha$-LA released the highest amount of tryptophan $(6.955 \mu \mathrm{mol} / \mathrm{g}$ of powder).

\section{DISCUSSION}

Our in vitro studies indicate that the hydrolytic conditions of the gut negate the need for prior hydrolysis of WPI from an antioxidant bioactivity viewpoint. The $\alpha$-LA, of the 4 major whey protein fractions studied, showed the highest antioxidant properties post-SGID 
when tested by ORAC, ABTS, and FRAP. This appears to accord with a high level of digestion $(57.59 \%$ $\mathrm{DH}$ ) and greatest release of the antioxidant AA tryptophan, $6.955 \mu \mathrm{mol}$ of tryptophan/g of protein.

Conditions in the stomach and duodenum (pepsin, trypsin, chymotrypsin, and acidic $\mathrm{pH}$ ) appear to func- tionalize WPI in reducing ferric ions, inhibiting ABTS and scavenging peroxyl radicals possibly by the release of bioactive peptides and AA. In agreement, PowerGrant et al. (2015) observed that WPC exposed to simulated SGID had significantly higher ORAC values $(36,305 \pm 3,390 \mu \mathrm{mol}$ of Trolox/100 g of powder) than
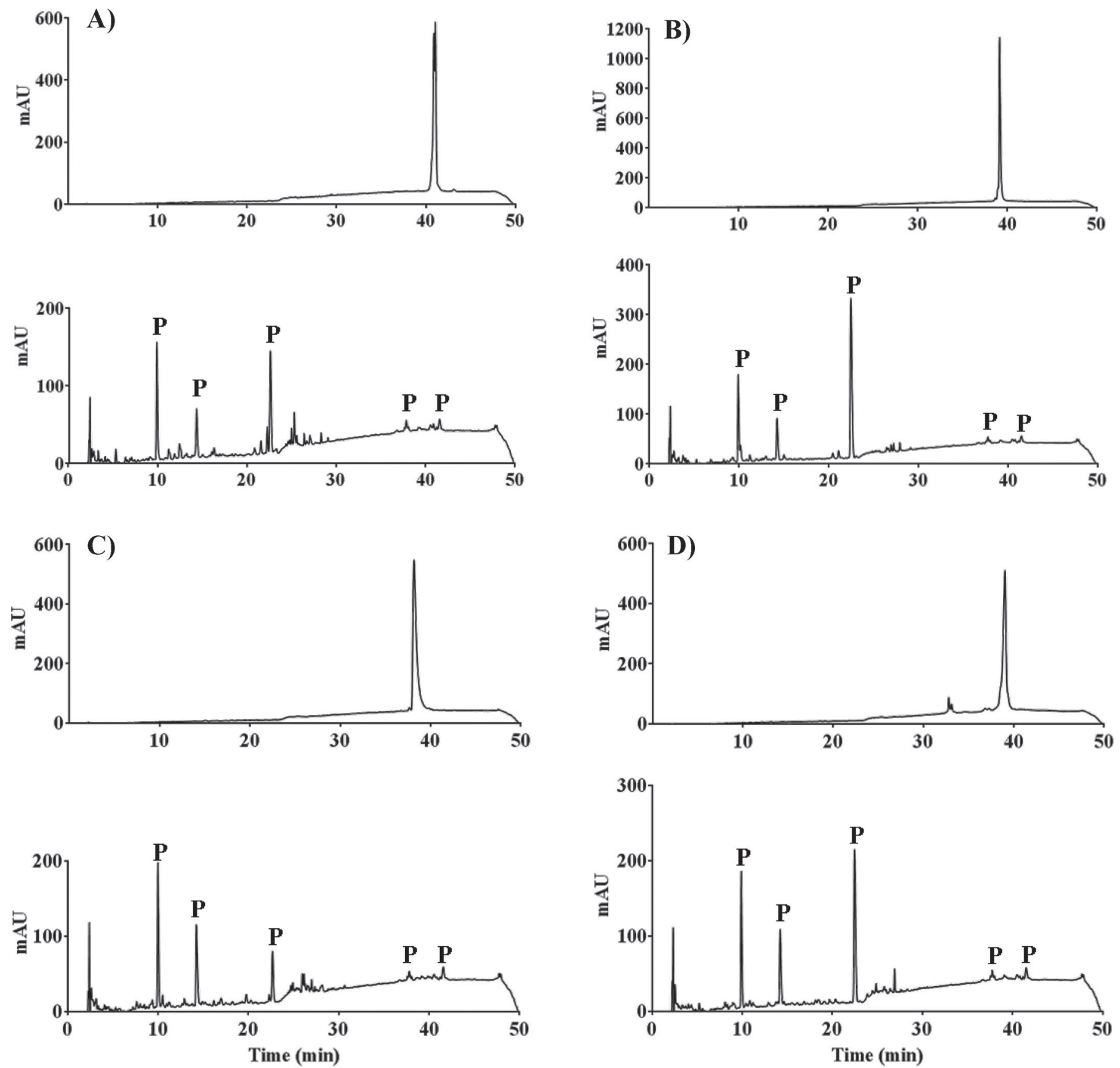

Figure 4. Reverse-phase HPLC profiles at $214 \mathrm{~nm}$ for individual whey proteins at $2 \mathrm{mg} / \mathrm{mL}$ and eluted in $0.1 \%$ trifluoroacetic acid. (A) Intact $\beta$-LG and the graph below it simulated gastrointestinal-digested (SGID) $\beta$-LG; (B) intact $\alpha$-LA and SGID $\alpha$-LA; (C) intact BSA and SGID BSA; and (D) intact lactoferrin and SGID lactoferrin. $\mathrm{P}=$ peaks corresponding to pancreatin; $\mathrm{AU}=$ arbitrary units. 


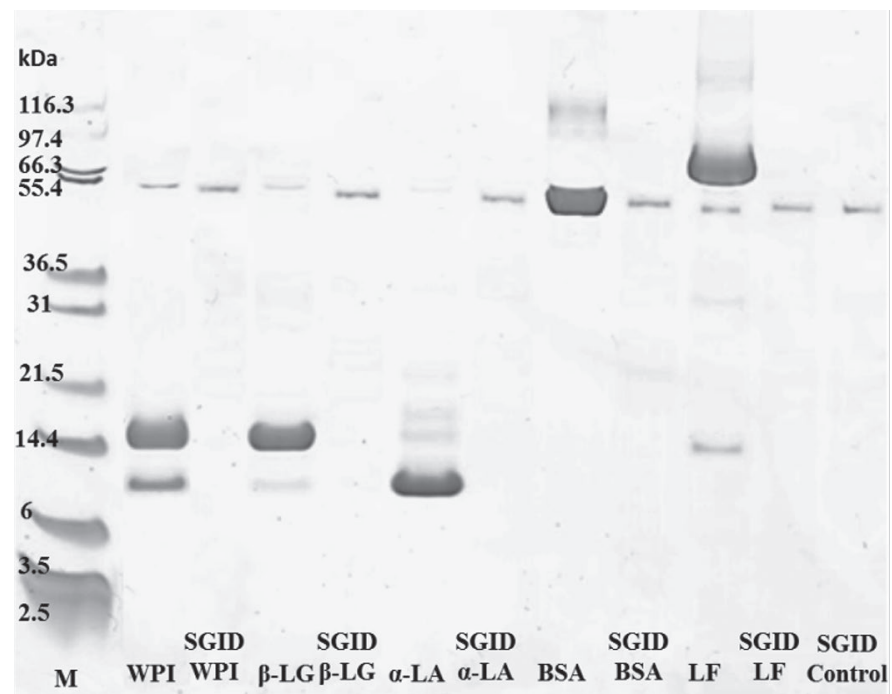

Figure 5. Nonreducing SDS-PAGE analysis of intact and simulated gastrointestinal-digested (SGID) whey proteins. Concentration $=6.5 \mu \mathrm{g}$ powder $/$ well. $\mathrm{M}=$ molecular weight marker; $\mathrm{WPI}=$ whey protein isolate; $\mathrm{LF}=$ lactoferrin; SGID control $=$ electrolytes + pepsin + pancreatin bile extract + protease inhibitor.

intact WPC $(13,662 \pm 1,018 \mu \mathrm{mol}$ of Trolox/100 g of powder). Similar to our study, antioxidant activity post-SGID was similar to that obtained with WPC hydrolyzed $(32 \% \mathrm{DH})$ beforehand $(37,391 \pm 2,298 \mu \mathrm{mol}$ of Trolox/100 g of powder). Interestingly, prior hydrolysis of WPC appeared to influence the antioxidant activity after simulated upper gut transit. The WPC with a $\mathrm{DH}$ of $45 \%$ at processing and then subjected to gastric conditions exhibited $60,613 \pm 4,540 \mu \mathrm{mol}$ of $\mathrm{TE} / 100$ $\mathrm{g}$ by ORAC assay, whereas a WPC hydrolysate $(32 \%$ DH) when subjected to gastric conditions had 44,489 \pm $2,064 \mu \mathrm{mol}$ of TE/100 g. Of note was the significant decrease in ORAC values for the WPC hydrolysate $(\mathrm{DH}$ $45 \%$ ) post-SGID compared with its non-SGID equivalent. We found no differences in ORAC values between the WPC hydrolysate DH $32 \%$ pre- and post-SGID. In contrast, other forms of processing designed to denature whey proteins, such as high hydrostatic pressure, may increase antioxidant activity even after SGID. Iskandar et al. (2015) observed that hydrostatic pressure at 550 $\mathrm{MPa}$ for $1 \mathrm{~min}$ at $20^{\circ} \mathrm{C}$ of WPI can enhance its WPI ferric-reducing activity by $21 \%$ after SGID (Iskandar et al., 2015). Pressurized WPI subjected to SGID also protected intestinal cells from oxidative stress after 23 $\mathrm{h}$ of treatment (Piccolomini et al., 2012).

The DH for WPI obtained in our study after SGID is in agreement with $\mathrm{He}$ et al. (2015), who showed a $49 \%$ digestibility by TNBS method after $3 \mathrm{~h}$ of digestion. However, these values are higher than the ones obtained by Conway et al. (2013) for WPC $(8.2 \pm 0.5 \%)$ after $2 \mathrm{~h}$ of pepsin digestion followed by $3 \mathrm{~h}$ of trypsin treatment. The lower protein degradation was also noticeable by SDS-PAGE, where, in Conway et al. (2013), the $\beta$-LG band was visible after the digestion process. Adjonu et al. (2013) also obtained DH values ranging between 12 and $13 \%$ for WPI hydrolyzed 12 to $24 \mathrm{~h}$ by

Table 2. Free AA released from $1 \mathrm{~g}$ of protein powder following simulated gastrointestinal digestion

\begin{tabular}{|c|c|c|c|c|c|}
\hline $\mathrm{AA}, \mu \mathrm{mol} / \mathrm{g}$ of powder & $\mathrm{WPI}^{1}$ & $\beta-L G$ & $\alpha-\mathrm{LA}$ & BSA & $\mathrm{LF}$ \\
\hline Ala & 2.541 & 2.486 & 1.625 & 2.816 & 3.064 \\
\hline Arg & 2.195 & 2.270 & 1.422 & 4.253 & 4.900 \\
\hline Asp & 0.584 & 0.636 & 0.608 & 0.394 & 0.505 \\
\hline Cysteic acid & 0.584 & 0.131 & 0.257 & 0.105 & 0.286 \\
\hline Cys & 1.389 & 1.255 & 1.251 & 1.118 & 1.123 \\
\hline$\gamma$-Aminobutyric acid & & & 0.081 & & \\
\hline Glu & 1.823 & 1.347 & 2.596 & 1.766 & 1.498 \\
\hline Gly & 0.884 & 0.639 & 1.482 & 0.788 & 1.563 \\
\hline His & 1.858 & 1.856 & 1.990 & 2.807 & 2.347 \\
\hline Ile & 2.640 & 2.229 & 2.667 & 1.148 & 1.409 \\
\hline Leu & 7.683 & 8.154 & 6.094 & 7.527 & 6.208 \\
\hline Lys & 7.246 & 6.925 & 8.154 & 6.264 & 5.929 \\
\hline Met & 1.173 & 1.145 & 0.789 & 0.404 & 0.650 \\
\hline Methionine sulfone & & & & 0.059 & \\
\hline Phe & 2.723 & 2.545 & 3.454 & 5.861 & 4.593 \\
\hline Ser & 1.379 & 1.200 & 0.964 & 1.516 & 1.566 \\
\hline Taurine & 0.217 & 0.278 & 0.582 & 0.243 & 0.187 \\
\hline Thr & 2.633 & 1.585 & 3.269 & 2.380 & 2.608 \\
\hline Trp & 5.067 & 2.462 & 6.955 & 1.722 & 4.235 \\
\hline Tyr & 2.534 & 2.309 & 3.003 & 4.294 & 3.203 \\
\hline Val & 3.632 & 3.218 & 3.183 & 3.069 & 3.111 \\
\hline Total & 48.784 & 42.670 & 50.426 & 48.532 & 48.986 \\
\hline
\end{tabular}


gastrointestinal enzymes individually. This difference supports previous knowledge that DH can be markedly increased by combination of enzymes with different specificity (Lee and Hur, 2017), as in the INFOGEST protocol that more closely resembles in vivo conditions, and that the antioxidant activity is not defined by the DH (Peña-Ramos and Xiong, 2001). It is important to note that SGID samples in our study corresponded to the end of the intestinal phase. However, in vivo, the intestinal lumen will be exposed to these factions but also to less-hydrolyzed fractions arriving from the stomach (Dupont et al., 2010). Interestingly, Joubran et al. (2015) demonstrated that the antioxidant capacity of $\alpha-\mathrm{LA}$ increased in later digestion phases where an in vitro model of the infant gut was employed. The in vitro duodenal samples exhibited higher antioxidant activity than samples from an in vitro model of the adult duodenum. In contrast, in vitro gastric infant samples were less antioxidant than the adult samples. Antioxidant capacity of dairy proteins during gut transit is therefore not only influenced by gut location, but also life stage (Joubran et al.2015).

The SGID results may indicate that the release of free $\mathrm{AA}$, in addition to individual bioactive peptides, governs antioxidant activity. This is supported by the similar antioxidant activity obtained after whey protein hydrolysis with different enzymes. These samples are abundant in AA such as histidine, phenylalanine, and tryptophan, which can exert their antioxidant activity by hydrogen atom transfer (i.e ORAC and ABTS) and by electron transfer mechanisms (i.e., FRAP; Elias et al. 2008). Power-Grant et al. (2016) observed that tryptophan has an ORAC value of 1,773,102 $\pm 25,218$ $\mu \mathrm{mol}$ of TE/100 g of AA dry weight, methionine has an ORAC value of $545,413 \pm 6,528$, histidine has an ORAC value of $191,762 \pm 7,308$, and cysteine has an ORAC value of $167,600 \pm 9,077 \mu \mathrm{mol}$ of $\mathrm{TE} / 100 \mathrm{~g}$ of AA. Therefore, it was proposed that these AA play a major contributing role to milk protein concentrate antioxidant activity. However, it is also noteworthy that several peptides have been identified from whey hydrolysates using Corolase PP [AB Enzymes, Darmstadt, Germany; $\beta$-LG: f(15-18) VAGT, f(19-29) WYSLAMAASDI, f (24-26) MAA, f(42-46) YVEEL, f(71-74) IIAE, f(145-149) MHIRL; Hernández-Ledesma et al., 2005; O'Keeffe et al., 2017], thermolysin [EC 3.4.24.27; Q-LA: f(101-104) INYW, f(115-118) LDQW; Sadat et al., 2011], and trypsin [ $\beta-L G$ : f(15-20) VAGTWY; Power et al., 2014]. All of these hydrolysates showed antioxidant activity, and the individual peptides, once synthetized, also demonstrated antioxidant properties. Therefore, the antioxidant power of whey hydrolysates is likely to be generated by possible synergy between individual AA and encrypted peptides, which are released during whey protein hydrolysis.

Whey (WPI, WPC, and fresh whey) hydrolysates produced by alcalase have been identified with strong antioxidant activity (Kou et al., 2013; Zhang et al., 2013). We also observed that hydrolysis with alcalase produces hydrolysates with the highest antioxidant activity. Dryáková et al. (2010) observed the highest ABTS inhibition (54\%) after hydrolysis of WPC with alcalase. Lin et al. (2012) also described alcalase hydrolysates from WPC as the most potent ferric ionreducing (0.55 $\mathrm{mM} \mathrm{FeSO}_{4}$ equivalents) agents compared with other commercial enzymes pepsin, trypsin, and flavorzyme. Alcalase and neutrase hydrolysates from whey proteins also protected lung fibroblast and umbilical vein endothelial cells by boosting intracellular antioxidant defenses (Kong et al., 2012; O'Keeffe and FitzGerald, 2014). In fact, the hydrolysis of $\beta$-LG with alcalase produced the most antioxidant fraction containing the peptides $f(27-38)$ DIQKVAGTWYSL, f(33-38) GTWYSL, f(39-48) AMAASDISLL, f(40-48) MAASDISLL, f(61-73) ELKPTPEGDLEIL, f(87-98) IIAEKTKIPAVF, f(112-121) DTDYKKYLLF, and $\mathrm{f}(165-172)$ LSFNPTQL (Bamdad et al., 2017). It is important to note that antioxidant activities from commercial enzyme hydrolysates in our study are likely to be affected by the standard thermal step required for enzyme inactivation, which is known to affect protein denaturation and aggregation (Joyce et al., 2018). In addition, thermal processing influenced the peptide release from milk proteins (Kopf-Bolanz et al., 2014).

The most potent proteins inhibiting ABTS radical and reducing iron were $\mathrm{LF}$ and $\alpha-\mathrm{LA}$; the latter was also the more efficient at neutralizing peroxyl radicals in ORAC assay. In agreement with our study, Hernández-Ledesma et al. (2005) observed that hydrolysates obtained from $\alpha$-LA after $24 \mathrm{~h}$ of hydrolysis using individual gastric enzymes had significantly higher ORAC values than $\beta$-LG hydrolysates $(1.065 \pm 0.056$ and 0.701 $\pm 0.033 \mu \mathrm{mol}$ of Trolox $/ \mathrm{mg}$ of protein, respectively; Hernández-Ledesma et al., 2005). Camel whey protein, which is rich in $\alpha$-LA (27\%) but devoid of $\beta$-LG (Hailu et al., 2016), also exerted significantly higher ABTS radical inhibition than its bovine equivalent (Salami et al., 2010). However, Clausen et al. (2009) reported similar ORAC values for $25-\mu \mathrm{L}$ sample quantities of intact $\alpha-\mathrm{LA}(0.07 \pm 0.04 \mu M \mathrm{TE})$ and intact $\beta$-LG $(0.14$ $\pm 0.09 \mu M$ TE) isolated from bovine milk whey by size exclusion chromatography, which is in agreement with our ORAC values for intact $\alpha$-LA and $\beta$-LG. Recently, bovine $\alpha$-LA ( $97.2 \%$ protein) following an infant in vitro SGID also showed higher DPPH-scavenging potential compared with intact $\alpha$-LA (Joubran et al., 2017). 
Indeed, 4 synthesized dipeptides whose sequences are present in $\alpha$-LA sequence, EW (25-26 AA), WC (60-61 AA), YW (103-104 AA), and WL (104-105 AA and 118-119 AA), inhibited 50\% DPPH radical at concentrations ranging from 0.26 to $3.07 \mathrm{~m} M$ (Nongonierma and Fitzgerald, 2013). In our study, with a $\mathrm{DH}$ value of $57 \%, \alpha$-LA released the highest total concentration (17.441 $\mu \mathrm{mol}$ of AA/g of protein) of the most reactive AA against peroxyl radicals (tryptophan, methionine, histidine, cysteine, tyrosine, and phenylalanine) as described by Hernández-Ledesma et al. (2005) and Power-Grant et al. (2016).

\section{CONCLUSIONS}

In conclusion, pre-enzymatic hydrolysis of WPI (based on 3 commercially available proteases tested) does not enhance antioxidant activity during simulated gut transit. This implies that the proteolytic conditions of the gut are capable of generating equivalent antioxidant capacity during SGID of WPI. The $\alpha$-LA fraction exerted the best antioxidant properties, which are not only maintained after SGID but increased. This suggests that $\alpha$-LA is the preferred whey protein candidate to supplement food products to counteract free radicals in our body and boost antioxidant defenses.

\section{ACKNOWLEDGMENTS}

This research was supported by the Department of Agriculture, Food and the Marine (Dublin, Ireland; FIRM project 13 F 354-WheyGSH). A. R. Corrochano is in receipt of a Teagasc Walsh Fellowship. The authors kindly acknowledge the assistance of Anne Marie Mc Auliffe (Teagasc, Food Research Centre, Moorepark, Fermoy, Co. Cork, Ireland) to determine free amino acids and Laura Saenz Benita (Teagasc, Food Research Centre, Moorepark, Fermoy, Co. Cork, Ireland) to optimize HPLC conditions.

\section{REFERENCES}

Abadía-García, L., E. Castaño-Tostado, L. Ozimek, S. Romero-Gómez, C. Ozuna, and S. L. Amaya-Llano. 2016. Impact of ultrasound pretreatment on whey protein hydrolysis by vegetable proteases. Innov. Food Sci. Emerg. Technol. 37:84-90. https://doi.org/10.1016/ j.ifset.2016.08.010.

Adjonu, R., G. Doran, P. Torley, and S. Agboola. 2013. Screening of whey protein isolate hydrolysates for their dual functionality: Influence of heat pre-treatment and enzyme specificity. Food Chem. 136:1435-1443. https://doi.org/10.1016/j.foodchem.2012.09.053.

Adler-Nissen, J. 1979. Determination of the degree of hydrolysis of food protein hydrolysates by trinitrobenzenesulfonic acid. J. Agric. Food Chem. 27:1256-1262. https://doi.org/10.1021/jf60226a042.

Adler-Nissen, J. 1986. Enzymic hydrolysis of food proteins. Pages 110-169 in Enzymic Hydrolysis of Food Proteins. Elsevier Applied Science Publishers, New York, NY.
Bamdad, F., S. Bark, C. H. Kwon, J. W. Suh, and H. Sunwoo. 2017. Anti-inflammatory and antioxidant properties of peptides released from beta-lactoglobulin by high hydrostatic pressure-assisted enzymatic hydrolysis. Molecules 22. https://doi.org/10.3390/ molecules22060949.

Benzie, I. F. F., and J. J. Strain. 1996. The ferric reducing ability of plasma (FRAP) as a measure of "antioxidant power": The FRAP assay. Anal. Biochem. 239:70-76.

Capitani, C. D., A. C. L. Carvalho, D. P. Rivelli, S. B. M. Barros, and I. A. Castro. 2009. Evaluation of natural and synthetic compounds according to their antioxidant activity using a multivariate approach. Eur. J. Lipid Sci. Technol. 111:1090-1099. https://doi .org/10.1002/ejlt.200800215.

Clausen, M. R., L. H. Skibsted, and J. Stagsted. 2009. Characterization of major radical scavenger species in bovine milk through size exclusion chromatography and functional assays. J. Agric. Food Chem. 57:2912-2919. https://doi.org/10.1021/jf803449t.

Cloetens, L., J. Panee, and B. Åkesson. 2013. The antioxidant capacity of milk-The application of different methods in vitro and in vivo. Cell. Mol. Biol. 59:43-57. https://doi.org/10.1170/t946.

Conway, V., S. F. Gauthier, and Y. Pouliot. 2013. Antioxidant activities of buttermilk proteins, whey proteins, and their enzymatic hydrolysates. J. Agric. Food Chem. 61:364-372. https://doi.org/ 10.1021/jf304309g.

de Aguilar-Nascimento, J. E., B. R. Prado Silveira, and D. B. DockNascimento. 2011. Early enteral nutrition with whey protein or casein in elderly patients with acute ischemic stroke: A doubleblind randomized trial. Nutrition 27:440-444. https://doi.org/10 .1016/j.nut.2010.02.013.

de Castro, R. J. S., and H. H. Sato. 2014. Advantages of an acid protease from Aspergillus oryzae over commercial preparations for production of whey protein hydrolysates with antioxidant activities. Biocatal. Agric. Biotechnol. 3:58-65. https://doi.org/10.1016/j .bcab.2013.11.012.

Dryáková, A., A. Pihlanto, P. Marnila, L. Čurda, and H. J. T. Korhonen. 2010. Antioxidant properties of whey protein hydrolysates as measured by three methods. Eur. Food Res. Technol. 230:865-874. https://doi.org/10.1007/s00217-010-1231-9.

Dupont, D., G. Mandalari, D. Molle, J. Jardin, J. Léonil, R. M. Faulks, M. S. J. Wickham, E. N. C. Mills, and A. Mackie. 2010. Comparative resistance of food proteins to adult and infant in vitro digestion models. Mol. Nutr. Food Res. 54:767-780. https://doi.org/10 $.1002 /$ mnfr.200900142.

Elias, R. J., S. S. Kellerby, and E. A. Decker. 2008. Antioxidant activity of proteins and peptides. Crit. Rev. Food Sci. Nutr. 48:430-441. https://doi.org/10.1080/10408390701425615.

Fernández, A., and P. Kelly. 2016. pH-stat vs. free-fall pH techniques in the enzymatic hydrolysis of whey proteins. Food Chem. 199:409-415. https://doi.org/10.1016/j.foodchem.2015.12.043.

Fiedor, J., and K. Burda. 2014. Potential role of carotenoids as antioxidants in human health and disease. Nutrients 6:466-488. https: //doi.org/10.3390/nu6020466.

Guerra, A., L. Etienne-Mesmin, V. Livrelli, S. Denis, S. BlanquetDiot, and M. Alric. 2012. Relevance and challenges in modeling human gastric and small intestinal digestion. Trends Biotechnol. 30:591-600. https://doi.org/10.1016/j.tibtech.2012.08.001.

Hailu, Y., E. B. Hansen, E. Seifu, M. Eshetu, R. Ipsen, and S. Kappeler. 2016. Functional and technological properties of camel milk proteins: A review. J. Dairy Res. 83:422-429. https://doi.org/10 $.1017 /$ S0022029916000686.

He, Z., B. Yuan, M. Zeng, G. Tao, and J. Chen. 2015. Effect of simulated processing on the antioxidant capacity and in vitro protein digestion of fruit juice-milk beverage model systems. Food Chem. 175:457-464. https://doi.org/10.1016/j.foodchem.2014.12.007.

Hernández-Ledesma, B., A. Davalos, B. Bartolome, and L. Amigo. 2005. Preparation of antioxidant enzymatic hydrolysates from lactalbumin and lactoglobulin. Identification of active peptides by HPLC-MS/MS. J. Agric. Food Chem. 53:588-593. https://doi .org $/ 10.1021 / \mathrm{jf0} 48626 \mathrm{~m}$.

Iskandar, M. M., L. C. Lands, K. Sabally, B. Azadi, B. Meehan, N. Mawji, C. D. Skinner, and S. Kubow. 2015. High hydrostatic pres- 
sure pretreatment of whey protein isolates improves their digestibility and antioxidant capacity. Foods 4:184-207. https://doi.org/ 10.3390/foods4020184.

Joubran, Y., A. Moscovici, and U. Lesmes. 2015. Antioxidant activity of bovine alpha lactalbumin Maillard products and evaluation of their in vitro gastro-duodenal digestive proteolysis. Food Funct. 6:1229-1240. https://doi.org/10.1039/c4fo01165a.

Joubran, Y., A. Moscovici, R. Portmann, and U. Lesmes. 2017. Implications of the Maillard reaction on bovine alpha-lactalbumin and its proteolysis during in vitro infant digestion. Food Funct. 8:2295-2308. https://doi.org/10.1039/c7fo00588a.

Joyce, A. M., A. L. Kelly, and J. A. O'Mahony. 2018. Controlling denaturation and aggregation of whey proteins during thermal processing by modifying temperature and calcium concentration. Int. J. Dairy Technol. 71:446-453. https://doi.org/10.1111/1471 $-0307.12507$.

Kong, B., X. Peng, Y. L. Xiong, and X. Zhao. 2012. Protection of lung fibroblast MRC-5 cells against hydrogen peroxide-induced oxidative damage by $0.1-2.8 \mathrm{kDa}$ antioxidative peptides isolated from whey protein hydrolysate. Food Chem. 135:540-547. https://doi .org/10.1016/j.foodchem.2012.04.122.

Koopman, R., N. Crombach, A. P. Gijsen, S. Walrand, J. Fauquant, A. K. Kies, S. Lemosquet, W. H. Saris, Y. Boirie, and L. J. van Loon. 2009. Ingestion of a protein hydrolysate is accompanied by an accelerated in vivo digestion and absorption rate when compared with its intact protein. Am. J. Clin. Nutr. 90:106-115. https://doi .org/10.3945/ajen.2009.27474.

Kopf-Bolanz, K. A., F. Schwander, M. Gijs, G. Vergères, R. Portmann, and L. Egger. 2014. Impact of milk processing on the generation of peptides during digestion. Int. Dairy J. 35:130-138. https://doi .org/10.1016/j.idairyj.2013.10.012.

Kou, X., J. Gao, Z. Xue, Z. Zhang, H. Wang, and X. Wang. 2013. Purification and identification of antioxidant peptides from chickpea (Cicer arietinum L.) albumin hydrolysates. Lebensm. Wiss. Technol. 50:591-598. https://doi.org/10.1016/j.lwt.2012.08.002.

Laemmli, U. K. 1970. Cleavage of structural proteins during the assembly of the head of bacteriophage T4. Nature 227:680-685.

Lee, S. Y., and S. J. Hur. 2017. Antihypertensive peptides from animal products, marine organisms, and plants. Food Chem. 228:506-517. https://doi.org/10.1016/j.foodchem.2017.02.039.

Li, S., H. Y. Tan, N. Wang, Z. J. Zhang, L. Lao, C. W. Wong, and Y. Feng. 2015. The role of oxidative stress and antioxidants in liver diseases. Int. J. Mol. Sci. 16:26087-26124. https://doi.org/10 $.3390 /$ ijms 161125942 .

Lin, S., W. Tian, H. Li, J. Cao, and W. Jiang. 2012. Improving antioxidant activities of whey protein hydrolysates obtained by thermal preheat treatment of pepsin, trypsin, alcalase and flavourzyme. Int. J. Food Sci. Technol. 47:2045-2051. https://doi.org/10.1111/j .1365-2621.2012.03068.x.

Liu, J., X. Wang, and Z. Zhao. 2014. Effect of whey protein hydrolysates with different molecular weight on fatigue induced by swimming exercise in mice. J. Sci. Food Agric. 94:126-130. https://doi .org/10.1002/jsfa.6220.

Liu, R., L. Xing, Q. Fu, G. H. Zhou, and W. G. Zhang. 2016. A review of antioxidant peptides derived from meat muscle and by-products. Antioxidants 5:32. https://doi.org/10.3390/antiox5030032.

Lü, J. M., P. H. Lin, Q. Yao, and C. Chen. 2010. Chemical and molecular mechanisms of antioxidants: Experimental approaches and model systems. J. Cell. Mol. Med. 14:840-860. https://doi.org/10 .1111/j.1582-4934.2009.00897.x.

Madureira, A. R., C. I. Pereira, A. M. P. Gomes, M. E. Pintado, and F. X. Malcata. 2007. Bovine whey proteins-Overview on their main biological properties. Food Res. Int. 40:1197-1211. https:// doi.org/10.1016/j.foodres.2007.07.005.

McDermott, A., G. Visentin, M. De Marchi, D. P. Berry, M. A. Fenelon, P. M. O'Connor, O. A. Kenny, and S. McParland. 2016. Prediction of individual milk proteins including free amino acids in bovine milk using mid-infrared spectroscopy and their correlations with milk processing characteristics. J. Dairy Sci. 99:3171-3182. https://doi.org/10.3168/jds.2015-9747.
Minekus, M., M. Alminger, P. Alvito, S. Ballance, T. Bohn, C. Bourlieu, F. Carriere, R. Boutrou, M. Corredig, D. Dupont, C. Dufour, L. Egger, M. Golding, S. Karakaya, B. Kirkhus, S. Le Feunteun, U. Lesmes, A. Macierzanka, A. Mackie, S. Marze, D. J. McClements, O. Menard, I. Recio, C. N. Santos, R. P. Singh, G. E. Vegarud, M. S. J. Wickham, W. Weitschies, and A. Brodkorb. 2014. A standardised static in vitro digestion method suitable for food-An international consensus. Food Funct. 5:1113-1124. https://doi.org/ $10.1039 / \mathrm{c} 3$ fo60702j.

Mohammadian, M., and A. Madadlou. 2016. Characterization of fibrillated antioxidant whey protein hydrolysate and comparison with fibrillated protein solution. Food Hydrocoll. 52:221-230. https:// doi.org/10.1016/j.foodhyd.2015.06.022.

Nimalaratne, C., and J. Wu. 2015. Hen egg as an antioxidant food commodity: A review. Nutrients 7:8274-8293. https://doi.org/10 $.3390 /$ nu7105394.

Nongonierma, A. B., and R. J. Fitzgerald. 2013. Inhibition of dipeptidyl peptidase IV (DPP-IV) by tryptophan containing dipeptides. Food Funct. 4:1843-1849. https://doi.org/10.1039/c3fo60262a.

O'Keeffe, M. B., C. Conesa, and R. J. FitzGerald. 2017. Identification of angiotensin converting enzyme inhibitory and antioxidant peptides in a whey protein concentrate hydrolysate produced at semi-pilot scale. Int. J. Food Sci. Technol. 52:1751-1759. https:// doi.org/10.1111/ijfs.13448.

O'Keeffe, M. B., and R. J. FitzGerald. 2014. Antioxidant effects of enzymatic hydrolysates of whey protein concentrate on cultured human endothelial cells. Int. Dairy J. 36:128-135. https://doi.org/ 10.1016/j.idairyj.2014.01.013.

Önay-Ucar, E., N. Arda, M. Pekmez, A. M. Yilmaz, N. Boke-Sarikahya, S. Kirmizigul, and A. S. Yalcin. 2014. Comparison of antioxidant capacity, protein profile and carbohydrate content of whey protein fractions. Food Chem. 150:34-40. https://doi.org/10.1016/ j.foodchem.2013.10.119.

Ortega, L., A. Romero, C. Muro, and F. Riera. 2015. Antioxidant activity and functional properties of polymerized whey products by glycation process. Int. J. Polym. Sci. 2015:1-10. https://doi.org/ $10.1155 / 2015 / 154262$.

Peña-Ramos, E. A., and Y. L. Xiong. 2001. Antioxidative activity of whey protein hydrolysates in a liposomal system. J. Dairy Sci. 84:2577-2583. https://doi.org/10.3168/jds.S0022-0302(01)74711 $-\mathrm{X}$.

Piccolomini, A. F., M. M. Iskandar, L. C. Lands, and S. Kubow. 2012. High hydrostatic pressure pre-treatment of whey proteins enhances whey protein hydrolysate inhibition of oxidative stress and IL-8 secretion in intestinal epithelial cells. Food Nutr. Res. 56. https:// doi.org/10.3402/fnr.v56i0.17549.

Power, O., A. Fernández, R. Norris, F. A. Riera, and R. J. FitzGerald. 2014. Selective enrichment of bioactive properties during ultrafiltration of a tryptic digest of $\beta$-lactoglobulin. J. Funct. Foods 9:38-47. https://doi.org/10.1016/j.jff.2014.04.002.

Power, O., P. Jakeman, and R. J. FitzGerald. 2013. Antioxidative peptides: Enzymatic production, in vitro and in vivo antioxidant activity and potential applications of milk-derived antioxidative peptides. Amino Acids 44:797-820. https://doi.org/10.1007/ s00726-012-1393-9.

Power-Grant, O., C. Bruen, L. Brennan, L. Giblin, P. Jakeman, and R. J. FitzGerald. 2015. In vitro bioactive properties of intact and enzymatically hydrolysed whey protein: Targeting the enteroinsular axis. Food Funct. 6:972-980. https://doi.org/10.1039/c4fo00983e.

Power-Grant, O., W. G. McCormack, M. Ramia De Cap, M. AmigoBenavent, R. J. Fitzgerald, and P. Jakeman. 2016. Evaluation of the antioxidant capacity of a milk protein matrix in vitro and in vivo in women aged 50-70 years. Int. J. Food Sci. Nutr. 67:325334. https://doi.org/10.3109/09637486.2016.1153607.

Quirós-Sauceda, A. E., C. O. Chen, J. B. Blumberg, H. AstiazaranGarcia, A. Wall-Medrano, and G. A. Gonzalez-Aguilar. 2017. Processing 'Ataulfo' mango into juice preserves the bioavailability and antioxidant capacity of its phenolic compounds. Nutrients 9:1082. https://doi.org/10.3390/nu9101082. 
Re, R., N. Pellegrini, A. Proteggente, A. Pannala, M. Yang, and C. Rice-Evans. 1999. Antioxidant activity applying an improved ABTS radical cation decolorization assay. Free Radic. Biol. Med. 26:1231-1237.

Sadat, L., C. Cakir-Kiefer, M.-A. N'Negue, J.-L. Gaillard, J.-M. Girardet, and L. Miclo. 2011. Isolation and identification of antioxidative peptides from bovine $\alpha$-lactalbumin. Int. Dairy J. 21:214-221. https://doi.org/10.1016/j.idairyj.2010.11.011.

Salami, M., A. A. Moosavi-Movahedi, M. R. Ehsani, R. Yousefi, T. Haertle, J. M. Chobert, S. H. Razavi, R. Henrich, S. Balalaie, S. A. Ebadi, S. Pourtakdoost, and A. Niasari-Naslaji. 2010. Improvement of the antimicrobial and antioxidant activities of camel and bovine whey proteins by limited proteolysis. J. Agric. Food Chem. 58:3297-3302. https://doi.org/10.1021/jf9033283.

Sarmadi, B. H., and A. Ismail. 2010. Antioxidative peptides from food proteins: A review. Peptides 31:1949-1956. https://doi.org/10 $.1016 /$ j.peptides.2010.06.020.

Torkova, A., K. Ryazantzeva, E. Agarkova, M. Tsentalovich, A. Kruchinin, and T. Fedorova. 2016. Cheese whey catalytic conversion for obtaining a bioactive hydrolysate with reduced antige- nicity. Curr. Res. Nutr. Food Sci. 4:182-196. https://doi.org/10 .12944/CRNFSJ.4.Special-Issue-October.24.

Xu, W., B. H. Kong, and X. H. Zhao. 2014. Optimization of some conditions of neutrase-catalyzed plastein reaction to mediate ACEinhibitory activity in vitro of casein hydrolysate prepared by neutrase. J. Food Sci. Technol. 51:276-284. https://doi.org/10.1007/ s13197-011-0503-0.

Zhang, Q. X., H. Wu, Y. F. Ling, and R. R. Lu. 2013. Isolation and identification of antioxidant peptides derived from whey protein enzymatic hydrolysate by consecutive chromatography and Q-TOF MS. J. Dairy Res. 80:367-373. https://doi.org/10.1017/ S0022029913000320.

Zhidong, L., G. Benheng, C. Xuezhong, L. Zhenmin, D. Yun, H. Hongliang, and R. Wen. 2013. Optimisation of hydrolysis conditions for antioxidant hydrolysate production from whey protein isolates using response surface methodology. Ir. J. Agric. Food Res. 52:53-65.

Zulueta, A., M. J. Esteve, and A. Frígola. 2009. ORAC and TEAC assays comparison to measure the antioxidant capacity of food products. Food Chem. 114:310-316. https://doi.org/10.1016/j .foodchem.2008.09.033. 